\title{
Aplikasi Manajemen Kegiatan Kemahasiswaan STIKI Indonesia Berbasis WEB
}

\author{
${ }^{1}$ Ni Luh Wiwik Sri Rahayu Ginantra, ${ }^{2}$ Ketut Jaya Atmaja. \\ ${ }^{1,2}$ STMIK STIKOM INDONESIA \\ 1wiwik@stiki-indonesia.ac.id, ${ }^{2}$ ketutjayaatmaja@gmail.com
}

\begin{abstract}
ABSTRAK.STMIK STIKOM Indonesia merupakan perguruan tinggi swasta dibidang teknologi informasi di Bali dengan jenjang program strata satu (S1) yang ingin memberikan pelayanan unggul kepada mahasiswa.Kenyamanan mahasiswa dapat tercapai dengan selalu memberikan layanan informasi, baik informasi mengenai kegiatan perkuliahan maupun kegiatan kemahasiswaan yang diadakan oleh pihak kampus. Kegiatan kemahasiswaan merupakan salah satu kegiatan yang dapat menunjang soft skill mahasiswa dan dapat menjadi syarat dalam memenuhi Satuan Kredit Partisipasi (SKP) untuk salah satu syarat kelulusan. Permasalah yang terjadi saat ini pencatatan kegiatan kemahasiswaan dan penggunaan ruangan masih dilakukan secara manual dengan menggunakan papan tulis. Sering kali kegiatan tersebut dilaksanakan seiring dengan jadwal perkuliahan sehingga terjadi kendala penggunaan ruangan kegiatan. Hasil dari penelitian ini adalah sebuah aplikasi yang dapat memberikan kemudahaan dalam mengelola kegiatan dan penggunaan ruangan serta memudahkan mahasiswa untuk mendapatkan informasi kegiatan kemahasiswaan dikampus.
\end{abstract}

Kata Kunci: STMIK STIKOM, kemahasiswaan, aplikasi.

ABSTRACT.STMIK STIKOM Indonesia is one of Information Technology University of Bachelor Degree's in Bali. It is concerned on providing the ultimate service for the students. The comfortable of students can be achieved through the information services of lecturing and student activities are provided by campus. Student activity is the most important activity in order to support student soft skills, and to fulfill graduation requirements of participation credit Score, it is shortened by SKP. Problems that occur at this time recording student activities and the use of space is still done manually by using the blackboard, when it is carried out during the lecturing schedules, so that there are constraints on the use of room activities. The results of this study is an application that can provide kemudahaan in managing activities and use of space and facilitate students to obtain information on student affairs activities on campus. .

Keywords: STMIK STIKOM, student affairs, application.

\section{PENDAHULUAN}

STMIK STIKOM INDONESIA (STIKI) merupakan salah satu perguruan tinggi swasta di bidang teknologi informasi di Bali. Sebagai salah satu perguruan tinggi komputer jenjang program strata satu (S1). Untuk mengembangkan skill dan kemampuan dari mahasiswa STIKI tidak hanya dilakukan melalui perkuliahan di kelas, tetapi juga dilakukan melalui kegiatan kemahasiswaan. Kegiatan kemahasiswaan merupakan kegiatan ekstrakurikuler yang bertujuan untuk memperkaya wawasan mahasiswa yang kegiatannya dilakukan diluar kurikulum perkuliahan. Kegiatan kemahasiswaan merupakan suatu sarana bagi mahasiswa untuk membekali diri melalui berbagai keahlian dan keterampilan tambahan yang didapatkan selain dari pengetahuan akademik yang diberikan melalui kurikulum perkuliahan. Sehingga diharapakan mahasiswa tidak saja menguasai pengetahuan akademik, tetapi juga memiliki soft skill yang baik. Kegiatan kemahasiswaan secara mendasar mencakup penalaran dan keilmuan, minat dan bakat, dan kesejahteraan jasmani maupun rohani. Bentuk kegiatan kemahasiswaan dirancang dan dilaksanakan oleh mahasiswa melalui wadah kegiatan kemahasiswaan di bawah bimbingan dan koordinasidari Pembantu Ketua III Bidang Kemahasiswaan.

Selama ini untuk pelaksanaan kegiatankemahasiswaan dan penggunaan ruangan kegiatan dilakukan dengan cara manual yaitu menggunakan papan pengumuman. Dengan cara seperti ini, terkadang ditemukan kendala seperti kurangnya informasi kegiatan dan penggunaan ruangan untuk kegiatan kemahasiswaan sehingga menyebabkan jadwal antara satu kegiatan dengan kegiatan lain berjalan bersamaan. Sehingga diperlukan sebuah aplikasi untuk memanajemen kegiatan kemahasiswaan yang dilakukan mahasiswa, untuk mempermudah dalam hal manajemen kegiatan kemahasiswaan dan mengatur ketersediaan ruangan. 


\section{LANDASAN TEORI}

\subsection{Sistem}

Menurut Jogianto $(2008,34)$ sistem dapat didefinisikan dengan pendekatan prosedur dan pendekatan komponen. Dengan pendekatan prosedur, sistem dapat didefiniskan sebagai kumpulan dari prosedur-prosedur yang mempunyai tujuan tertentu. Dengan pendekatan komponen, sistem dapat didefinisikan sebagai kumpulan komponen yang salah berhubungan satu dengan yang lainnya membentuk satu kesatuan untuk mencapai tujuan tertentu. Contoh sistem yang didefinisikan dengan pendekatan ini misalnya adalah sistem komputer yang didefinisikan sebagai kumpulan dari perangkat keras dan perangkat lunak.

Sistem juga merupakan kumpulan elemen-elemen yang saling terkait dan bekerja sama untuk memproses masukan (input) yang ditujukan kepada sistem tersebut dan mengelola masukan tersebut sampai menghasilkan keluaran (output) yang diinginkan.(Kristanto, 2008).

\subsection{Website}

Menurut Kadir (2006,2-4), World Wide Web (WWW) atau biasa disebut dengan Web merupakan salah satu sumberdaya internet yang berkembang pesat. Saat ini, informasi Web didistribusikan melalui pendekatan hyperlink, yang memungkinkan suatu teks, gambar, ataupun objek yang lain menjadi acuan untuk membuka halaman-halaman web yang lain. Dengan pendekatan hyperlink ini, seseorang dapat memperoleh informasi dengan meloncat dari suatu halaman ke halaman yang lain. Halaman-halaman yang diakses pun dapat tersebar di berbagai mesin bahkan di berbagai negara.Website memberikan informasi, gambaran serta visualisasi orang atau lembaga yang membuatnya.

Aplikasi web sendiri dapat dibagi menjadi web statis dan web dinamis. Web statisdibentuk dengan menggunakan HTML saja. Kekurangan aplikasi ini terletak padakeharusan untuk memelihara program secara terus-menerus untuk mengikuti setiapperubahan yang terjadi. Kelamahan ini dapat diatasi dengan model aplikasi web dinamis.

\subsection{Data Flow Diagram (DFD)}

Menurut Pohan dan Bakri (1997, 16-19), Model ini menggambarkan sistem sebagai jaringan kerja antar fungsi yang berhubungansatu sama lain dengan aliran dan penyimpanan data (selanjutnya kita sebut dengan DFD). Sebagai perangkat analisis, model ini hanya mampu memodelkan sistem dari satu sudut pandang yaitu sudutpandang fungsi. Ada empat komponen:

\section{Proses}

Proses umumnya didefinisikan dengan kata tunggal, atau kalimat sederhana. Pada sejumlah kasus definisi ini dapat berupa nama departemen, bagian dalam suatu organisasi, komputer, peralatan mekanik. Sehingga definisi tadi lebih sering mengidentifikasikan subyek proses daripada obyek proses itu sendiri. Simbol untuk proses dalam DFD dapat dilihat pada gambar 2.

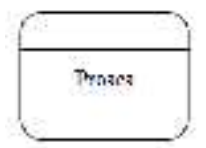

Gambar Error! No text of specified style in document.. Contoh proses

\section{Aliran Data}

Komponen ini dipresentasikan dengan menggunakan panah yang menuju ke / dari proses. Digunakan untuk menggambarkan gerakan paket data atau informasi dari satu bagian ke bagian lain dari sistem dimana penyimpanan mewakili lokasi penyimpanan data. Pada sejumlah kasus, seperti pada sistem yang sangat kompleks, aliran ini menggambarkan materi. Nama berfungsi untuk mendefinisikan arti dari aliran tersebut dan ditulis untuk mengidentifikasi aliran tersebut. Ujung panah menunjukkan kemana data bergerak ke / dari proses, penyimpanan ataupun terminator atau keduanya. Aliran yang digambarkan sebagai panah dengan dua ujung menggambarkan terjadinya dialog.

Aliran dapat juga menyebar atau menyatu, misalnya sejumlah atribut dapat membentuk satu aliran, atau satu aliran menyebar menjadi sejumlah atribut. Atribut dalam hal dapat merupakan bagiasn atau duplikasi dari aliran. Simbol untuk aliran data dalam DFD dapat dilihat pada gambar 3 . 


\section{Data Store}

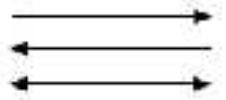

Gambar 3.Contoh Aliran

Komponen ini digunakan untuk memodelkan kumpulan data. Kumpulan data yang disimpan dengan cara tertentu. Data yang mengalir disimpan dalam data store. Aliran data diupdate atau ditambahkan ke dalam data store. Simbol untuk data store dalam DFD dapat dilihat pada gambar 4 .

\section{Data Store}

\section{External Entity}

Gambar 4. Contoh Penyimpanan

Komponen berikutnya dalam model ini dipresentasikan menggunakan persegi panjang, yang mewakili entity luar dimana sistem berkomunikasi. Biasanya notasi ini melambangkan orang atau kelompok orang misalnya organisasi di luar sistem, grup, departemen, perusahaan pemerintah, dan berada di luar kontrol sistem yang dimodelkan. Simbol untuk external entity dalam DFD dapat dilihat pada gambar 5.

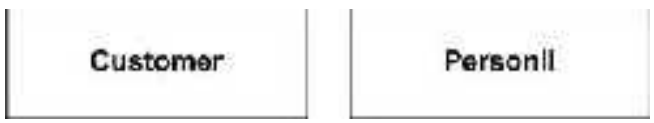

\subsection{BlackBox Testing}

\section{Gambar 5. Contoh External Entity}

Menurut Simarmata (2010, 316), klasifikasi blackbox testing mencakup beberapa pengujian salah satunya adalah pengujian fungsioanal (fuctional testing). Pada jenis pengujian ini, perangkat lunak diuji untuk persyaratan fungsional. Pengujian dilakukan dalam bentuk tertulis untuk memeriksa apakah aplikasi berjalan seperti yang diharapkan. Pengujian fungsional juga meliputi permukaan yang

\section{METODE PENELITIAN} jelas dari jenis fungsi-fungsi serta operasi back-end.

\subsection{Tempat dan Waktu Penelitian}

Penelitian dilakukan di STMIK STIKOM Indonesia yang beralamat di jalan Tukad Pakerisan No 97 Panjer, Denpasar, Bali. Penelitian ini dilakukan selama enam bulan, mulai dari bulan April 2017 sampai bulan September 2017.

\subsection{Teknik Pengumpulan Data}

\subsubsection{Observasi}

Observasi dilakukan dengan mengamati langsung sistem kerja di tempat penelitian yaitu STMIK STIKOM Indonesia. Observasi yang dilakukan mengenai kegiatan-kegiatan yang di lakukan oleh unit kegiatan kemahasiswaan dan proses peminjaman ruangan pada bagian kerumahtanggaan untuk pelaksanaan kegiatan tersebut.

\subsubsection{Kepustakaan}

Metode kepustakaan merupakan metode pengumpulan data dengan menganalisa kajian pustaka sebagai landasan teori. Data-data dan informasi yang didapat dari metode kepustakaan berasal dari buku, jurnal serta data dari berbagai sumber yang mendukung konsep dasar penelitian ini.

\subsection{Gambaran Umum Sistem}

Sistem yang dibangun memberikan gambaran tentang 3 komponen utama yaitu input, proses dan output. Input dari sistem adalah dataruangan, data kegiatan dan organisasi kemahasiswaa. Sistem melakukan proses filter ruangan yang tersedia, kemudian sistem akan melakukan filter kegiatan terdekat pada bulan tersebut dan akan dilakukan proses validasi oleh bagian sarana dan prasarana untuk ruangan yang tersedia. Output dari sistem adalah informasi kegiatan kemahasiswaan yang dapat diikuti oleh mahasiswa STMIK STIKOM Indonesia.Gambaran umum sistem yang dapat dibangun sebagai berikut : 


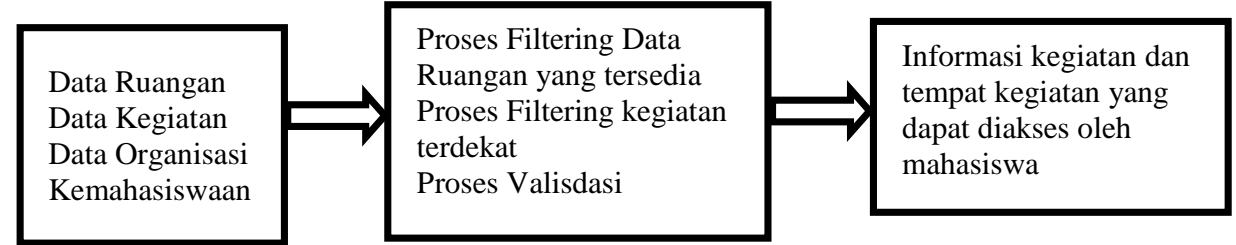

Gambar 6. Gambaran Umum Sistem

\subsection{Data Flow Diagram ( DFD)}

Konteks diagram adalah diagram yang terdiri dari satu proses utama dan menggambarkan ruang lingkup suatu sistem. Diagram konteks merupakan level tertinggi dari DFD yang menggambarkan seluruh input ke sistem atau output dari sistem.Diagram konteks dari aplikasi manajemen kegiatan kemahasiswaan dapat dilihat pada gambar 3.2

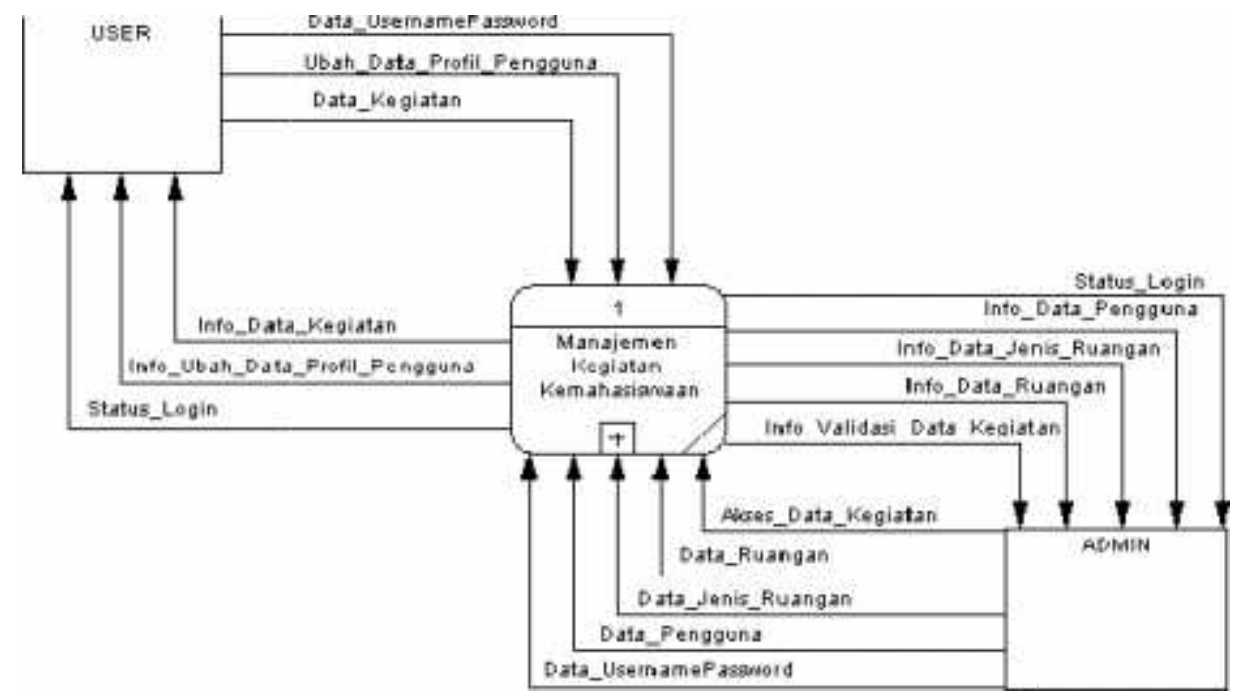

Gambar 7. Diagram Konteks Aplikasi Manajemen Kegiatan Kemahasiswaan

Diagram konteks pada aplikasi manajemen kegiatan kemahasiswaan ini terdiri dari satu proses utama yang bernama Manajemen Kegiatan Kemahasiswaan, dua entitas yaitu User dan Admin. User dapat login ke sistem, mengimput data kegiatan dan dapat mengubah data profil pengguna (user). Admin dapat login ke sistem, mengimput data pengguna, data ruangan dan dapat mengakses data kegiatan kemahasiswaan.

DFD level 0 pada gambar 8 memiliki lima proses yaitu proses login, mengelola data pengguna, mengelola data jenis ruangan, mengelola data ruangan dan mengelola data kegiatan. 


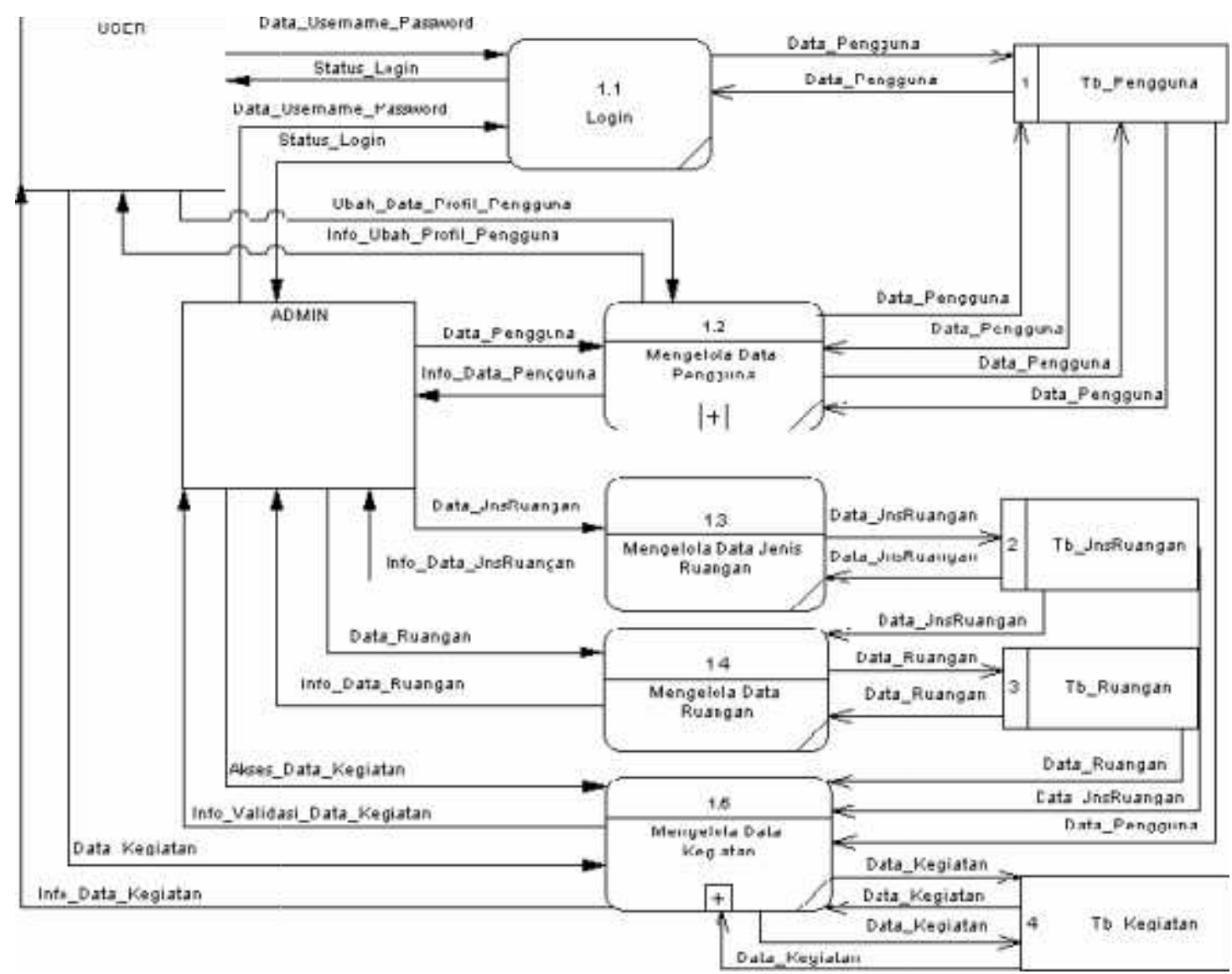

Gambar 8.DFD level 0 Aplikasi Manajemen Kegiatan Kemahasiswaan

DFD level 1 mengelola data kegiatan pada gambar 9 merupakan penjabaran dari proses mengelola data kegiatan pada DFD level 0. Pada DFD level 1 terdapat dua proses yaitu tambah kegiatan dan validasi kegiatan.

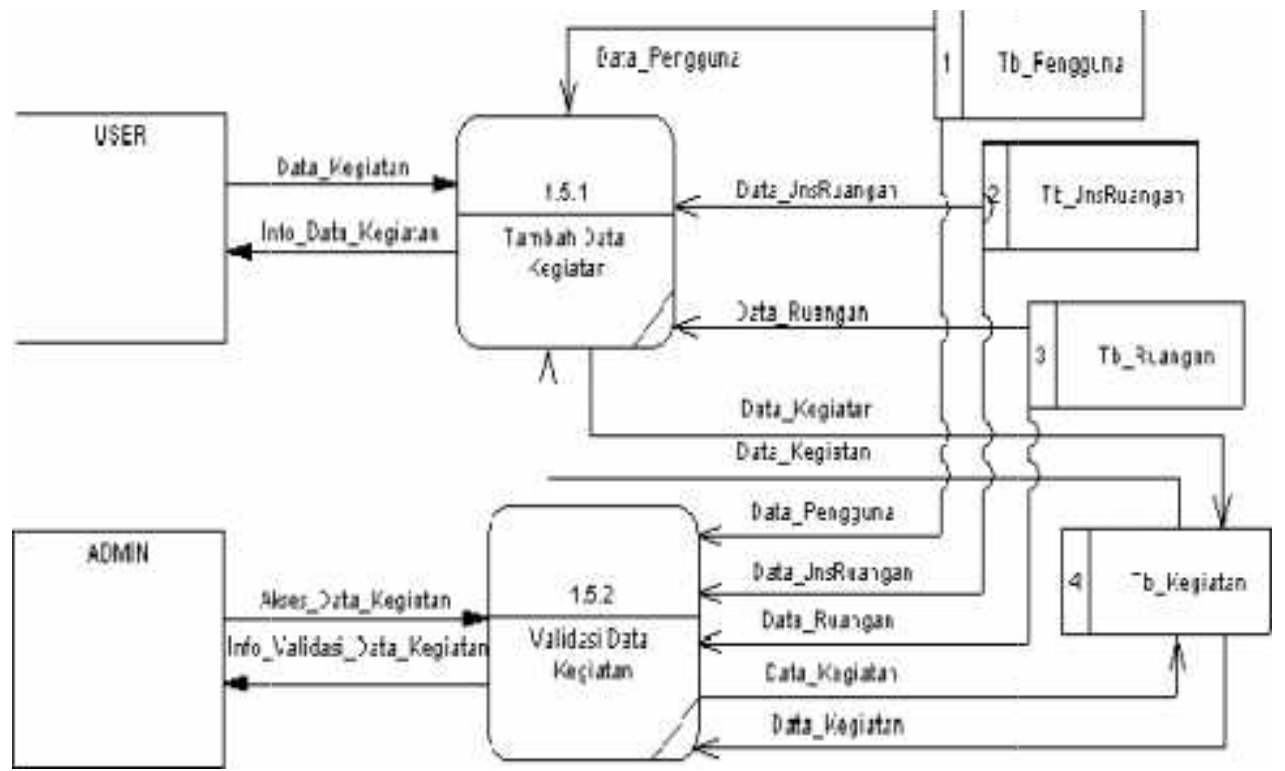

Gambar 9. DFD level 1 Mengelola Kegiatan

DFD level 1 mengelola data pengguna merupakan rincian dari mengelola data pengguna dari daari DFD level 0. Pada DFD level 1 mengelola data pengguna terdapatr dua proses yaitu tambah data pengguna dan ubah data pengguna. DFD level 1 mengelola data pengguna dapat dilihat pada gambar 10. 


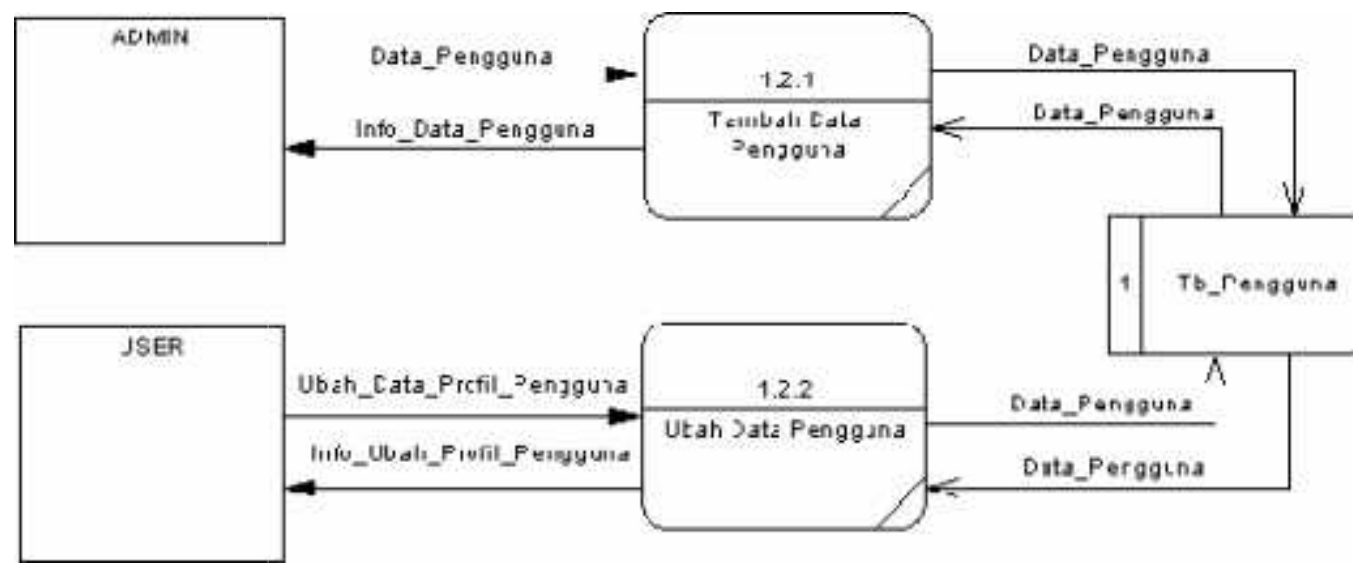

Gambar 10. DFD level 1 Mengelola Data Pengguna

\subsection{Entity Relationship Diagram (ERD)}

Entity Relationship Diagram (ERD) merupakan gambaran hubungan antar entitas yang digunakan dalam sistem. Perancangan ERD meliputi tahap penentuan entitas, penentuan atribut tiap entitas, penentuan relasi antar entitas, dan penentuan kardinalitas tiap entitas.Pada Entity Relationship Diagram (ERD) Aplikasi Manajemen Kegiatan Kemahasiswaan STIKI Indonesia Berbasis Web ini terdapat empat entitas utama yaitu Ruangan, Kegiatan, Jenis Ruangan dan Penggguna. Gambaran keterkaitan dan hubungan Entity Relationship Diagram (ERD) antar entitas dalam Aplikasi Manajemen Kegiatan Kemahasiswaan STIKI Indonesia Berbasis Web dapat dilihat pada gambar 11.

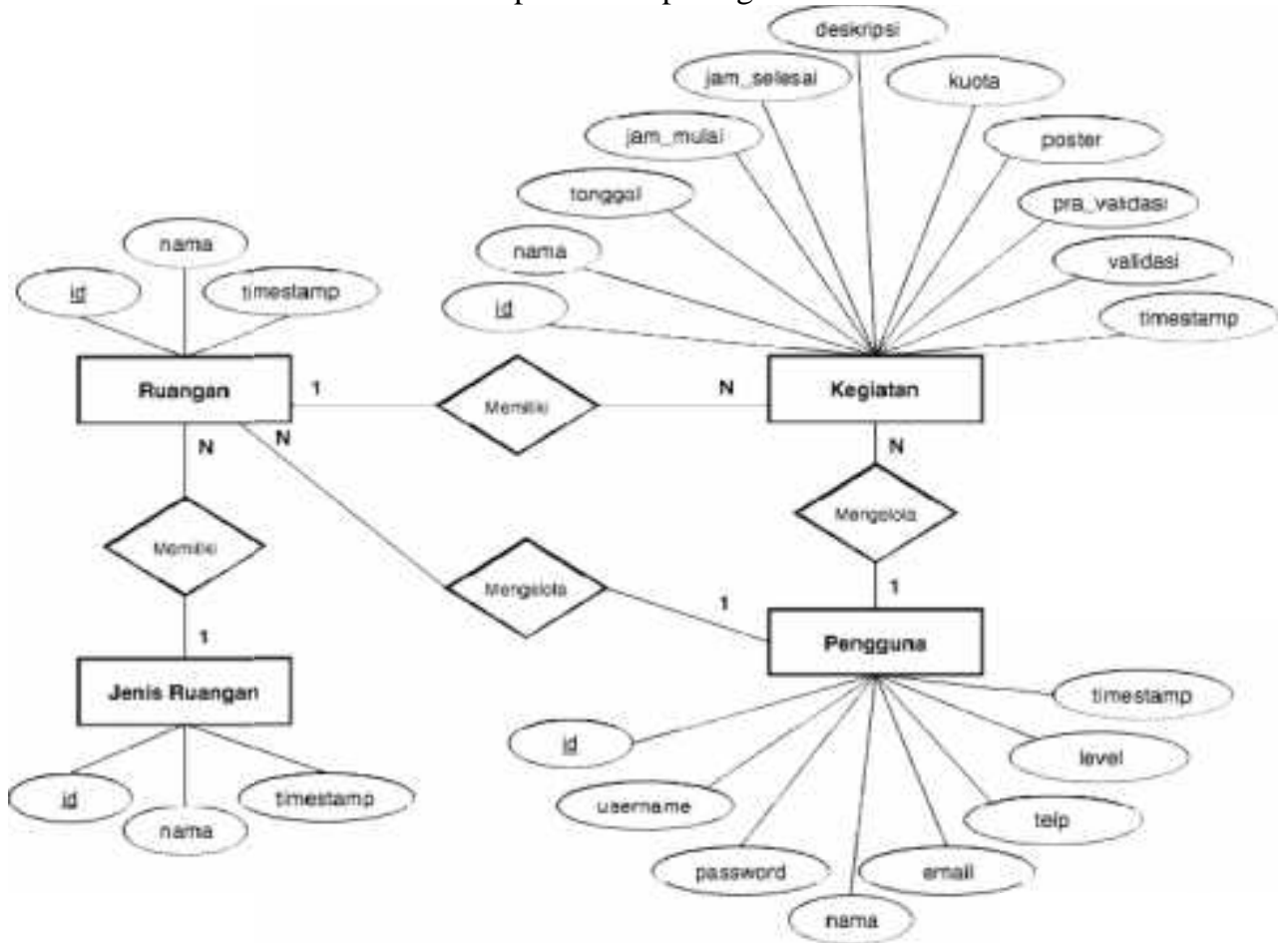

Gambar 11.Entity Relationship Diagram (ERD)

Struktur tabel dari hubungan antar tabel Aplikasi Manajemen Kegiatan Kemahasiswaan sebagai berikut :

Tabel 1 Ruangan

\begin{tabular}{lccl}
\hline \multicolumn{1}{c}{ Field } & Type Data & Length & \multicolumn{1}{c}{ Keterangan } \\
\hline id & Integer & - & Primary key \\
Nama & Varchar & 50 & Nama ruangan \\
Timestamp & Time & & Waktu input \\
\hline
\end{tabular}


Tabel 2 Jenis_Ruangan

\begin{tabular}{lccl}
\hline \multicolumn{1}{c}{ Field } & Type Data & Length & \multicolumn{1}{c}{ Keterangan } \\
\hline Id & Integer & - & Primary key \\
Nama & Varchar & 50 & Nama ruangan \\
Timestamp & Time & & Waktu input \\
\hline
\end{tabular}

Tabel 3 Pengguna

\begin{tabular}{lccl}
\hline \multicolumn{1}{c}{ Field } & Type Data & Length & \multicolumn{1}{c}{ Keterangan } \\
\hline Id & varchar & 5 & Primary key \\
username & Varchar & 50 & Nama user untuk login \\
Password & Varchar & 50 & Password user \\
Nama & Varchar & 50 & Nama pengguna \\
Email & Varchar & 100 & Alamat email pengguna \\
telpon & Varchar & 100 & Nomer telepon pengguna \\
level & Varchar & 20 & Kedudukan pengguna \\
Timestamp & Time & & Waktu input \\
\hline
\end{tabular}

Tabel 4 Kegiatan

\begin{tabular}{lccl}
\hline \multicolumn{1}{c}{ Field } & Type Data & Length & \multicolumn{1}{c}{ Keterangan } \\
\hline Id & varchar & 9 & Primary key \\
Nama & Varchar & 200 & Nama kegiatan \\
tanggal & date & - & Tanggal kegiatan \\
Jam_mulai & Time & - & Waktu mulai kegiatan \\
Jam_selesai & Time & - & Waktu selesai kegiatan \\
Diskripsi & Long varchar & - & Uraian detail kegiatan \\
Kuota & interger & - & Batas jumlah peserta kegiatan \\
Poster & Long varchar & - & Poster kegiatan \\
Pra_Validasi & integer & - & Pra_Validasi kegiatan \\
Validasi & Integer & - & Validasi kegiatan \\
Timestamp & Time & - & Waktu input \\
\hline
\end{tabular}

\section{IMPLEMENTASI SISTEM}

\subsection{Halaman Utama}

Halaman utama merupakan halaman yang menampilkan informasi kegiatan dalam bentuk kalender kegiatan. Pada halaman ini terdapat logo, menu navigasi (Kalender Kegiatan dan Login) pada bagian kiri, dan terdapat tombol icon filteruntuk menampilkan kegiatan berdasarkan bulan, tahun, dan penyelenggara. Tampilan halaman utama dapat dilihat pada Gambar 12.

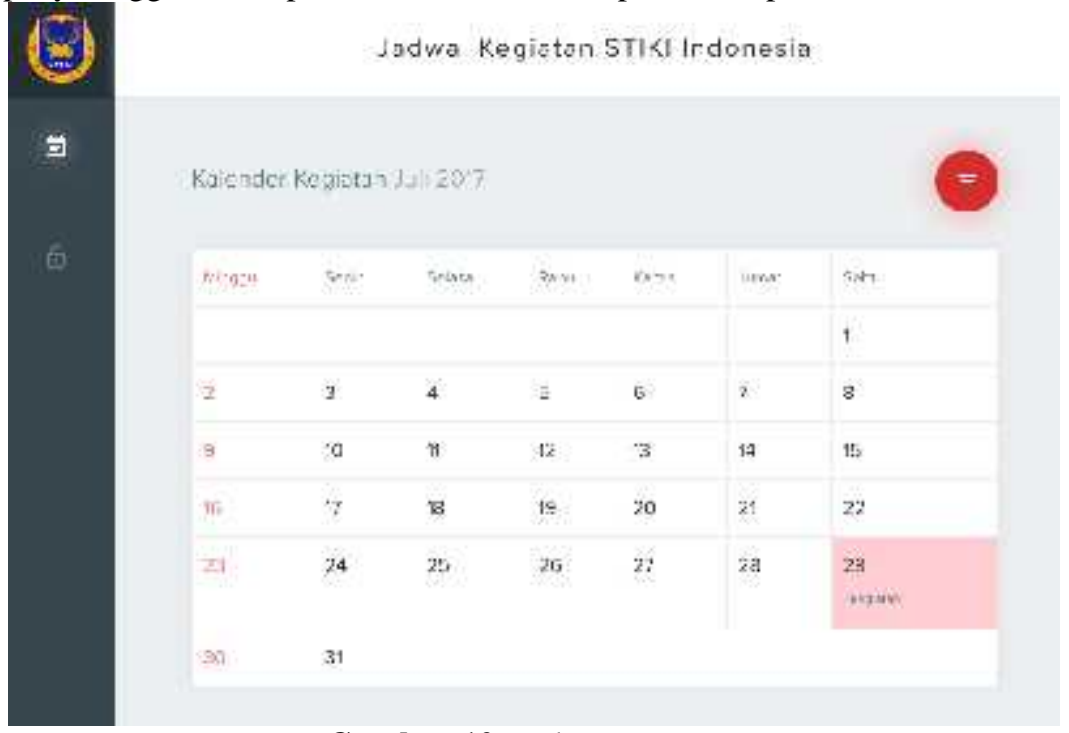

Gambar 12. Halaman Utama 


\subsection{Tampilan Filter Kegiatan}

Filter kegiatan berfungsi untuk memilih dan menampilkan kegiatan berdasarkan bulan, tahun, dan penyelenggara. Setelah menekan icon filteryang berwarna merah maka akan tampil form filter kegiatan, seperti yang ditunjukkan pada Gambar 13.

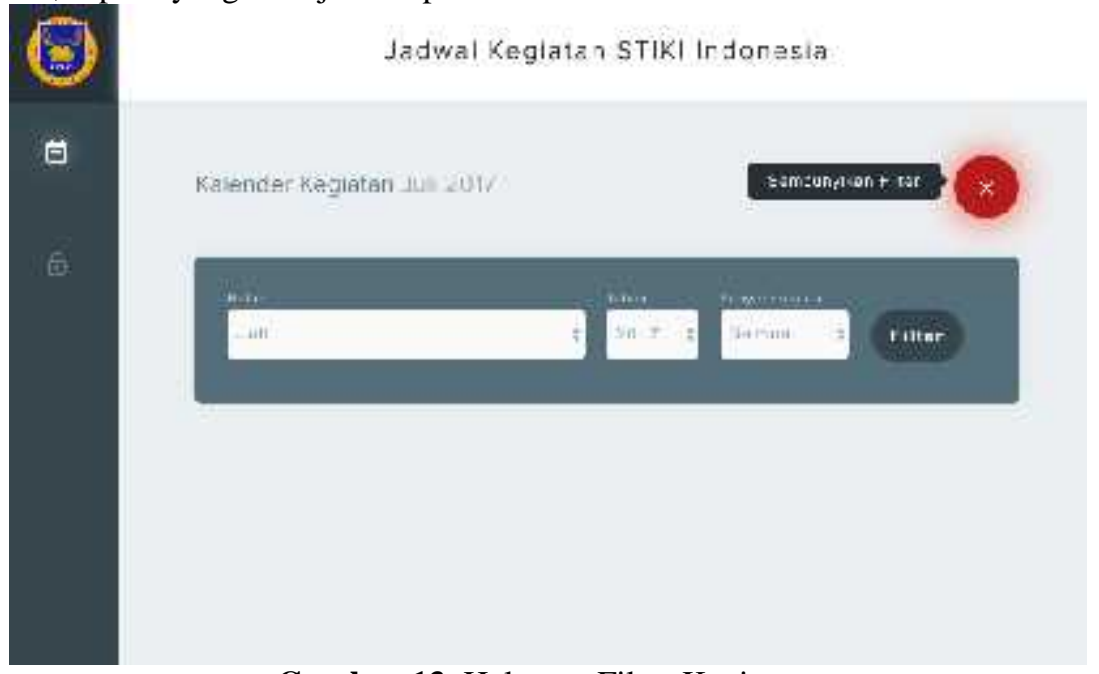

Gambar 13. Halaman Filter Kegiatan

Hasil filter kegiatan menampilkan informasi kegiatan yang tersedia pada bulan, tahun, atau penyelenggara yang dipilih. Pada kalender akan ditandai dengan warna merah (tanggal dan jumlah kegiatan). Tampilan hasil filter kegiatan dapat dilihat pada Gambar 14.

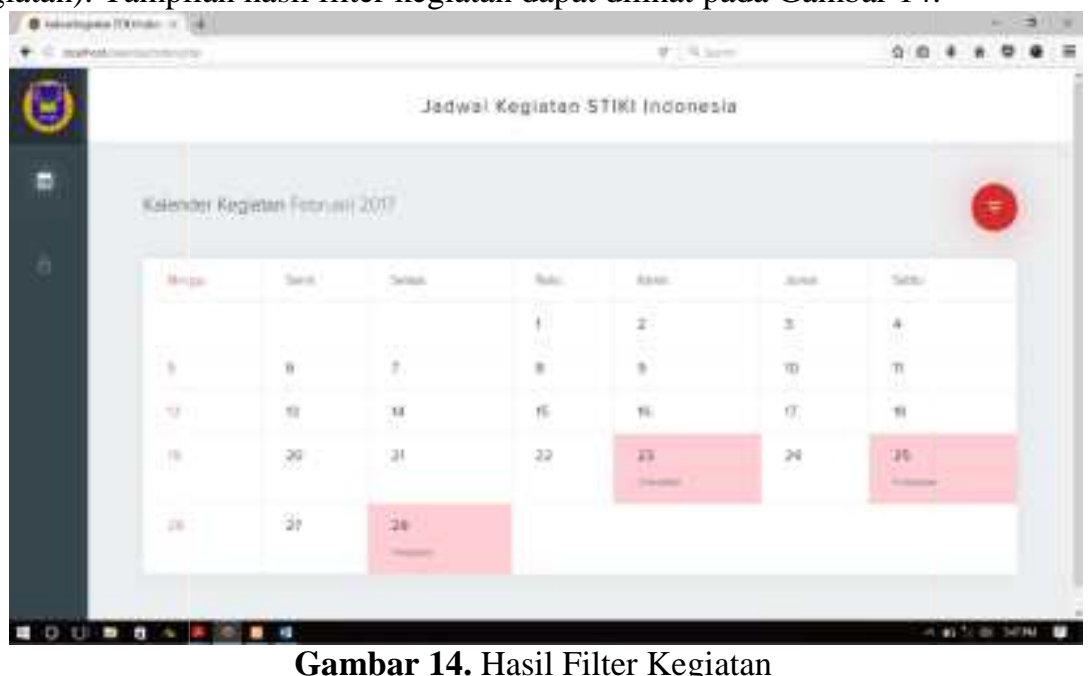

\subsection{Halaman Login}

Gambar 14. Hasil Filter Kegiatan

Halaman login merupakan halaman yang menampilkan form untuk masuk kedalam sistem agar pengelola dapat mengelola data-data yang terdapat pada database. Terdapat dua textinput yaitu username dan password. Tampilan halaman login dapat dilihat pada Gambar 15. 


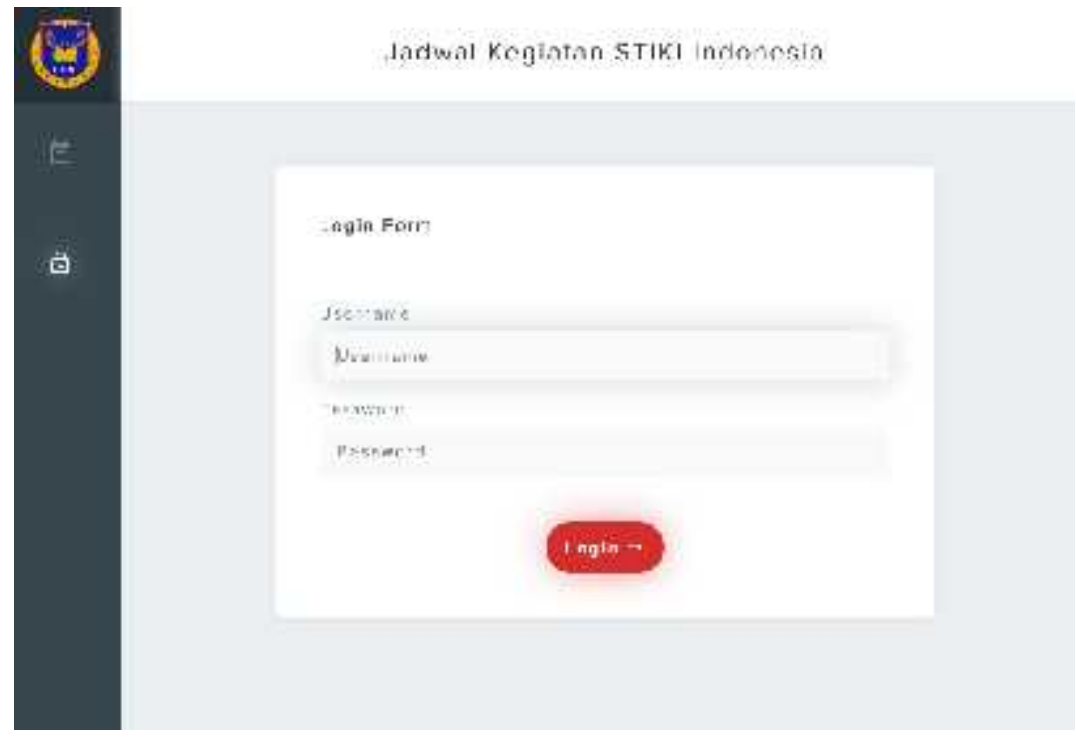

Gambar 15. Halaman Login

\subsection{Halaman Mengelola Data Kegiatan}

Halaman mengelola data kegiatan merupakan halaman yang pertama kali tampil saat pengguna (Lembaga dan Kemahasiswaan) berhasil login. Pada halaman ini terdapat logo, menu navigasi (Daftar Kegiatan, Ubah Profil, dan Logout) pada bagian kiri, tombol icon Tambah Kegiatanuntuk menambahkan kegiatan, dan terdapat tabel yang menampilkan daftar kegiatan yang dibuat oleh pengguna yang bersangkutan. Tampilan halaman mengelola data kegiatan dapat dilihat pada Gambar 16.

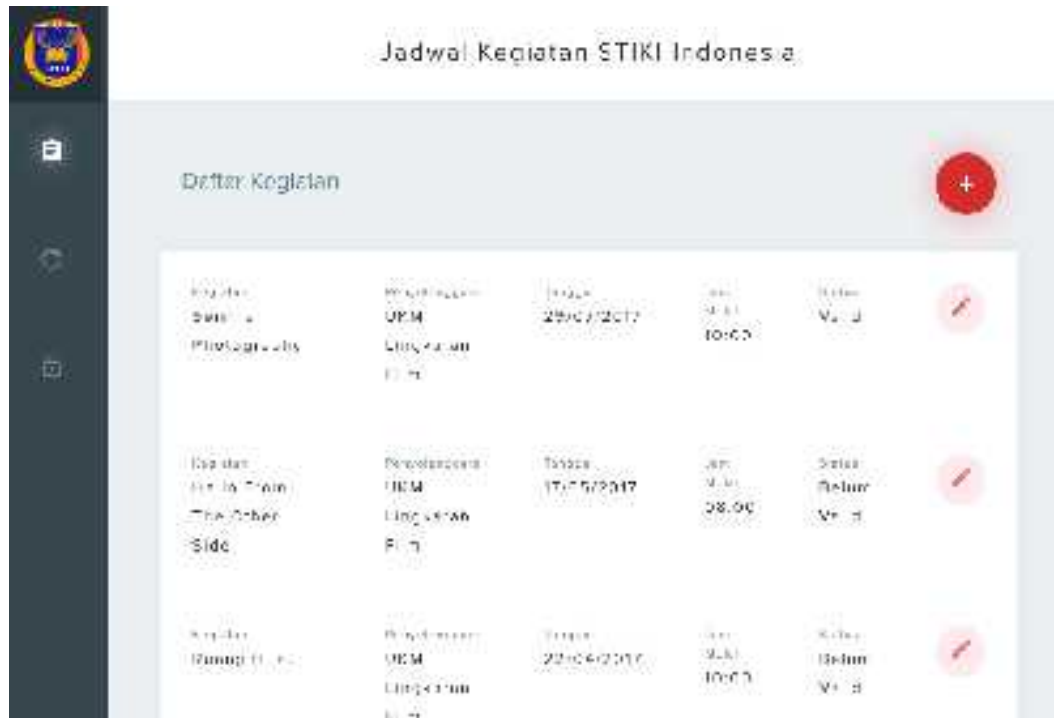

Gambar 16. Halaman Mengelola Kegiatan

\subsection{Halaman Validasi Ruangan dan Waktu Kegiatan}

Halaman validasi ruangan dan waktu kegiatan ini adalah fitur yang dipergunakan untuk mencegah terjadinya input tempat dan waktu kegiatan yang sama. Fitur tersebut dapat mempermudah administrator dalam melakukan validasi kegiatan, sehingga administrator tidak perlu memeriksa apakah ada kegiatan yang dilaksanakan pada tempat dan waktu yang bersamaan. Fitur tersebut diimplementasikan pada halaman tambah data kegiatan, seperti yang ditunjukkan oleh Gambar 17. 


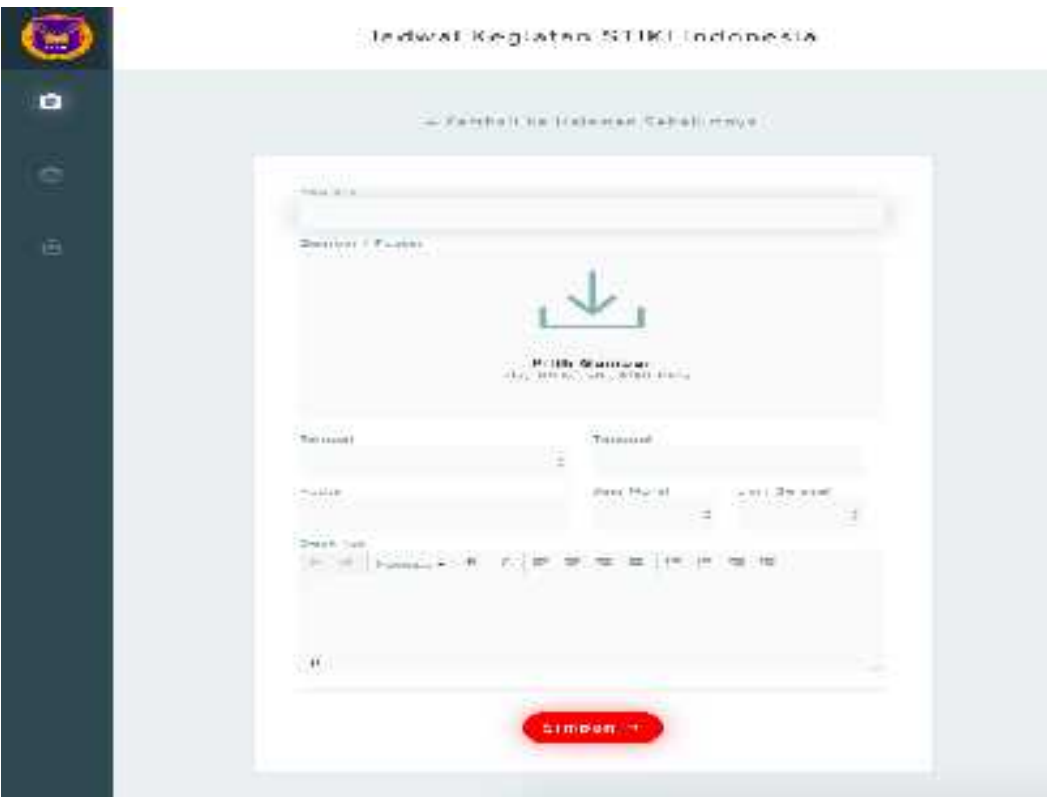

Gambar 17. Halaman Tambah Kegiatan

Apabila terdapat pemilihan tempat dan waktu kegiatan yang sama, maka user tidak akan bisa memilih waktu yang sama di tempat tersebut, karena sudah dipakai oleh kegiatan yang lainnya seperti yang ditunjukkan Gambar 18.

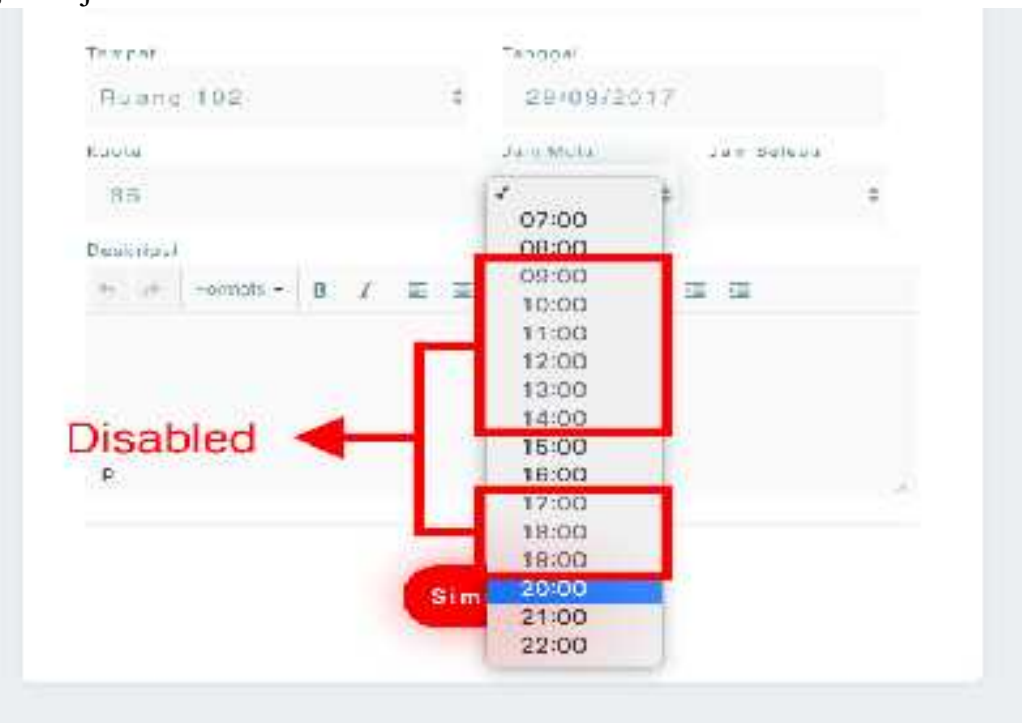

\subsection{Halaman Validasi Data Kegiatan}

Gambar 18. Pengelolaan Ruang dan Waktu Kegiatan

Halaman validasi data kegiatan merupakan halaman yang dikelola oleh Administrator. Halaman ini menampilkan daftar kegiatan yang akan datang. Untuk memvalidasi data kegiatan pengguna dapat menekan tombol icon Validasi Kegiatan seperti yang terlihat pada Gambar 19. 


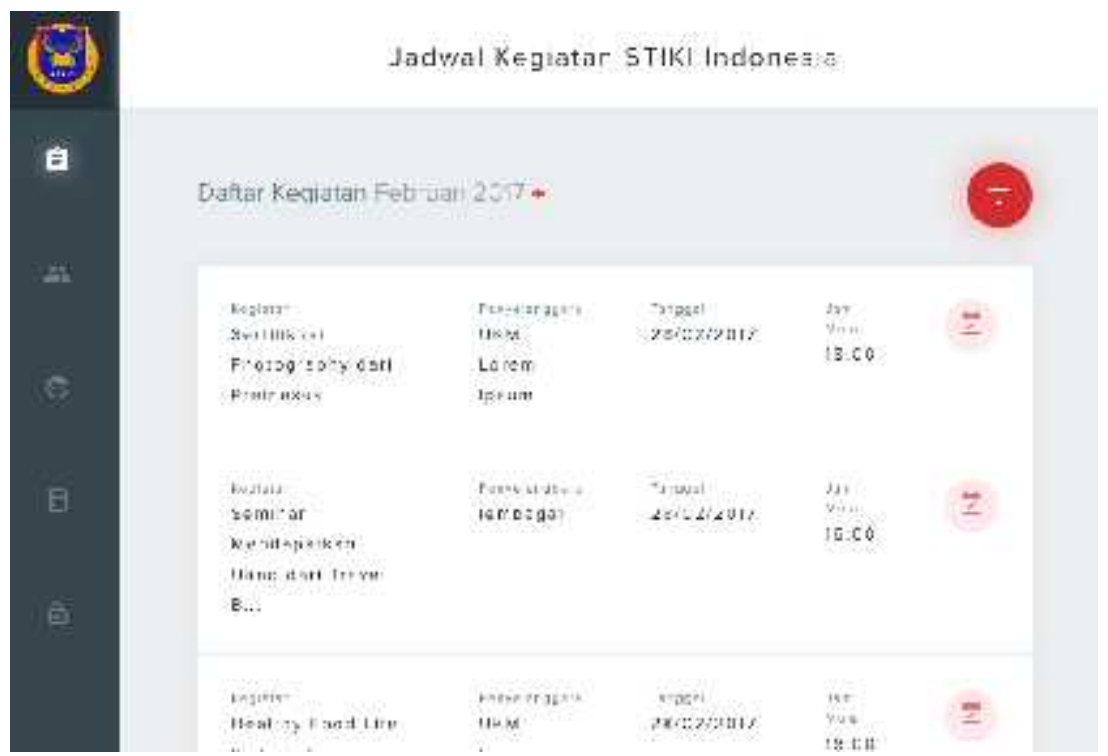

\subsection{Halaman Mengelola Data Pengguna}

Gambar 19. Halaman Validasi Kegiatan

Halaman mengelola data pengguna merupakan halaman yang dikelola oleh Administrator. Halaman ini berisi daftar pengguna (Administrator, Lembaga, dan Kemahasiswaan). Terdapat icon tombol tambah dan icon pensil untuk tombol ubah pada masing-masing baris data pengguna. Tampilan halaman mengelola data pengguna dapat dilihat pada Gambar 20.

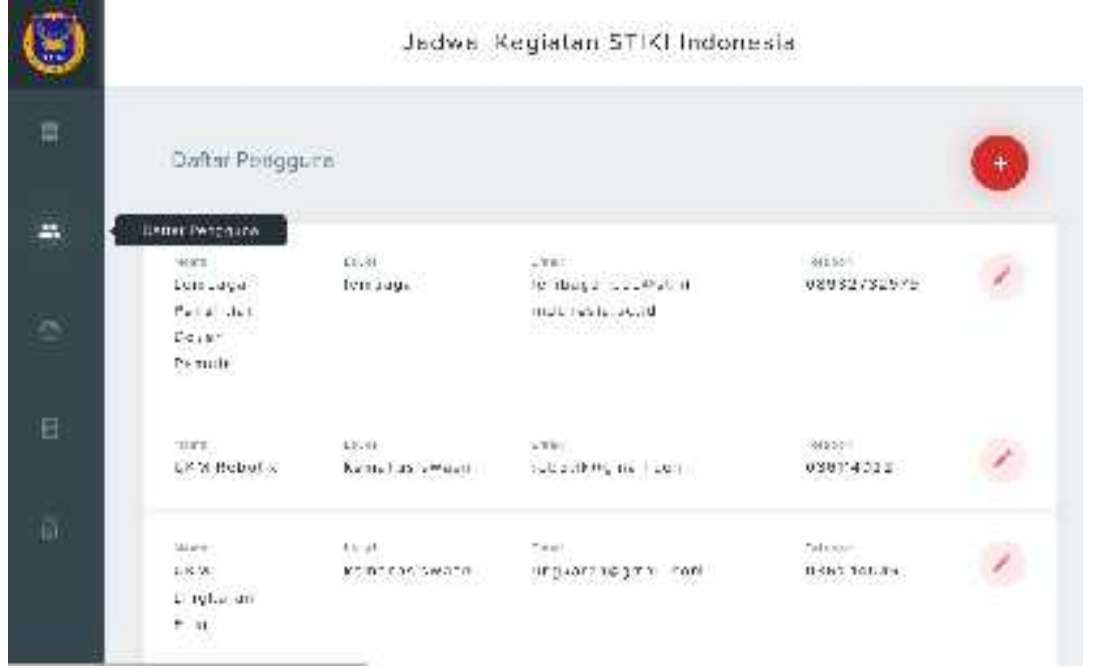

Gambar 20. Halaman Mengelola Pengguna

\subsection{Halaman Mengelola Data Ruangan}

Halaman mengelola data ruangan merupakan halaman yang dikelola oleh Administrator. Pada halaman ini terdapat logo, menu navigasi (Daftar Kegiatan, Daftar Pengguna, Ubah Profil, Daftar Ruangan, dan Logout) pada bagian kiri, tombol icon Tambah Ruanganuntuk menambahkan ruangan baru, dan terdapat tabel yang menampilkan daftar ruangan. Tampilan halaman mengelola data ruangan dapat dilihat pada Gambar 21. 


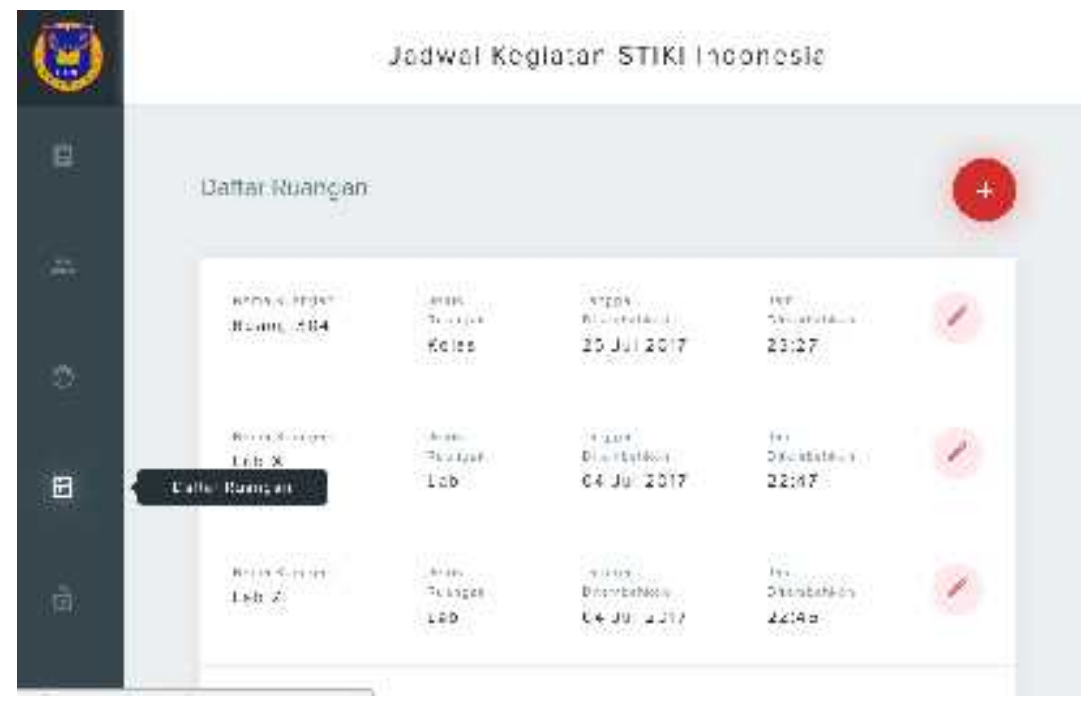

\section{PENGUJIAN SISTEM}

Gambar 21. Halaman Mengelola Data Ruangan

\subsection{Pengujian BlackBox Halaman Back-end.}

Pengujian blackbox halaman back-end ini meliputi beberapa proses yang terjadi pada halaman, diantaranya adalah : halaman login, halaman daftar kegiatan yang akan datang dan halaman daftar ruangan. Adapun ruang lingkup proses yang diuji adalah: proses login, validasi kegiatan, tambah (pengguna dan ruangan), ubah (pengguna dan ruangan), dan logout. Hasil pengujian blackbox halaman back-end (Administrator) dapat dilihat pada Tabel 5.

Tabel 5. Pengujian Blackbox Halaman Back-end.

\begin{tabular}{|c|c|c|c|}
\hline No & Skenario Pengujian & Hasil Yang Diharapkan & Hasil Pengujian \\
\hline 1 & $\begin{array}{l}\text { Isi username dan } \\
\text { password dengan benar, } \\
\text { klik tombol login }\end{array}$ & $\begin{array}{l}\text { Masuk ke halaman daftar } \\
\text { kegiatan akan datang }\end{array}$ & $\begin{array}{l}\text { Masuk ke halaman daftar } \\
\text { kegiatan akan datang }\end{array}$ \\
\hline 2 & $\begin{array}{l}\text { Isi username dan } \\
\text { password yang salah, } \\
\text { klik tombol login }\end{array}$ & $\begin{array}{l}\text { Muncul pemberitahuan } \\
\text { username dan password salah }\end{array}$ & $\begin{array}{l}\text { Muncul pemberitahuan " } \\
\text { Username atau Password } \\
\text { Tidak Valid!" }\end{array}$ \\
\hline 3 & $\begin{array}{l}\text { Klik menu daftar } \\
\text { kegiatan akan datang }\end{array}$ & $\begin{array}{l}\text { Menampilkan kegiatan yang } \\
\text { akan datang }\end{array}$ & $\begin{array}{l}\text { Menampilkan kegiatan } \\
\text { yang akan datang }\end{array}$ \\
\hline 4 & $\begin{array}{l}\text { Klik tombol tampilkan } \\
\text { filter pada halaman } \\
\text { kegiatan akan datang }\end{array}$ & $\begin{array}{l}\text { Menampilkan form filter bulan, } \\
\text { tahun, dan penyelenggara }\end{array}$ & $\begin{array}{l}\text { Menampilkan form filter } \\
\text { bulan, tahun, dan } \\
\text { penyelenggara }\end{array}$ \\
\hline 5 & $\begin{array}{l}\text { Klik tombol validasi } \\
\text { kegiatan }\end{array}$ & $\begin{array}{l}\text { Menampilkan informasi detail } \\
\text { kegiatan yang dipilih }\end{array}$ & $\begin{array}{l}\text { Menampilkan informasi } \\
\text { detail kegiatan yang } \\
\text { dipilih }\end{array}$ \\
\hline 6 & $\begin{array}{l}\text { Klik tombol validasi } \\
\text { pada detail kegiatan } \\
\text { yang dipilih }\end{array}$ & Kegiatan divalidasi & $\begin{array}{l}\text { Kegiatan divalidasi, } \\
\text { menampilkan pesan } \\
\text { "Validasi Berhasil!" }\end{array}$ \\
\hline 7 & $\begin{array}{l}\text { Klik menu daftar } \\
\text { pengguna }\end{array}$ & $\begin{array}{l}\text { Menampilkan halaman daftar } \\
\text { pengguna }\end{array}$ & $\begin{array}{l}\text { Menampilkan halaman } \\
\text { daftar pengguna }\end{array}$ \\
\hline 8 & $\begin{array}{l}\text { Klik menu daftar } \\
\text { ruangan }\end{array}$ & $\begin{array}{l}\text { Menampilkan halaman daftar } \\
\text { ruangan }\end{array}$ & $\begin{array}{l}\text { Menampilkan halaman } \\
\text { daftar ruangan }\end{array}$ \\
\hline 9 & $\begin{array}{l}\text { Klik tombol simpan } \\
\text { pada form tambah } \\
\text { ruangan (Semua field } \\
\text { diisi dengan benar) }\end{array}$ & $\begin{array}{l}\text { Simpan data ke database } \\
\text { kemudian menampilkan pesan } \\
\text { data berhasil ditambahkan }\end{array}$ & $\begin{array}{l}\text { Simpan data ke database } \\
\text { kemudian menampilkan } \\
\text { pesan "Data Berhasil } \\
\text { Ditambahkan!" }\end{array}$ \\
\hline 10 & $\begin{array}{l}\text { Klik tombol simpan } \\
\text { pada form tambah } \\
\text { ruangan (Semua }\end{array}$ & $\begin{array}{l}\text { Muncul pemberitahuan field } \\
\text { tidak boleh kosong }\end{array}$ & $\begin{array}{l}\text { Menampilkan pesan } \\
\text { "Please fill out the field." }\end{array}$ \\
\hline
\end{tabular}




\begin{tabular}{|c|c|c|}
\hline fielddikosongkan) & & \\
\hline 11 Klik menu logout & $\begin{array}{l}\text { Keluar dari halaman back-end } \\
\text { dan kembali ke halaman front- } \\
\text { end }\end{array}$ & $\begin{array}{l}\text { Keluar dari halaman } \\
\text { back-end dan kembali ke } \\
\text { halaman front-end }\end{array}$ \\
\hline
\end{tabular}

\subsection{Pengujian BlackBox Halaman Front-end.}

Pengujian blackbox halaman front-endini meliputi beberapa proses yang terjadi pada halaman pengguna secara umum. Pada halaman front-end ditampilkan daftar kegiatan dalam bentuk kalender kegiatan. Adapun ruang lingkup proses yang diuji adalah: proses mengakses kalender kegiatan dan filter kegiatan. Hasil pengujian blackbox halaman front-end dapat dilihat pada Tabel 6.

Tabel 6. Pengujian Blackbox Halaman Front-end

\begin{tabular}{|c|c|c|c|}
\hline NO & Skenario Pengujian & Hasil Yang Diharapkan & Hasil Pengujian \\
\hline 1 & $\begin{array}{l}\text { Mengakses halaman } \\
\text { utama }\end{array}$ & Menampilkan kalender kegiatan & $\begin{array}{l}\text { Menampilkan kalender } \\
\text { kegiatan pada bulan dan tahun } \\
\text { sekarang }\end{array}$ \\
\hline 2 & $\begin{array}{l}\text { Klik tombol filter } \\
\text { pada form filter }\end{array}$ & $\begin{array}{l}\text { Menampilkan kegiatan } \\
\text { berdasarkan bulan, tahun, atau } \\
\text { penyelenggara yang dipilih }\end{array}$ & $\begin{array}{l}\text { Menampilkan kegiatan } \\
\text { berdasarkan bulan, tahun, atau } \\
\text { penyelenggara yang dipilih }\end{array}$ \\
\hline 3 & $\begin{array}{l}\text { Klik tanggal pada } \\
\text { kalender yang berisi } \\
\text { kegiatan }\end{array}$ & $\begin{array}{l}\text { Menampilkan daftar kegiatan } \\
\text { yang terdapat pada tanggal } \\
\text { tersebut }\end{array}$ & $\begin{array}{l}\text { Menampilkan daftar kegiatan } \\
\text { yang terdapat pada tanggal } \\
\text { tersebut }\end{array}$ \\
\hline 4 & Klik menu login & Menampilkan halaman login & Menampilkan halaman login \\
\hline
\end{tabular}

\section{PENUTUP}

\subsection{Kesimpulan}

Kesimpulan yang dapat diambil berdasarkan pembahasan dan sistem yang dibangun adalah:

1. Penelitian ini diawali dengan melakukan pengumpulan data yang dibutuhkan, kemudian merancang alur sistem yang akan dibangun dan selanjutnya dilakukan implementasi sistem dengan menggunakan database MySql dan bahasa pemrograman PHP,HTML, CSS dan Javascript.

2. Pengujian sistem dilakukan dengan menganalisis komponen dan fungsi sistem dengan pengujian blackbox dan hasil pengujian menunjukan aplikasi berjalan dengan baik.

3. Aplikasi Manajemen Kegiatan Kemahasiswaan STIKI Indonesia Berbasis Web dapat memberikan kemudahan informasi kegiatan,nama kegiatan, kuota peserta dan jumlah skp serta tempat pelaksanaankegiatankepada mahasiswa STIKI Indonesia.

4. Aplikasi Manajemen Kegiatan Kemahasiswaan STIKI Indonesia Berbasis Web ini memberikan kemudahan bagian kemahasiswaan dalam monitoring kegiatan mahasiswa dan

\subsection{Saran} membantu bagian kerumahtanggan dalam mengatur ruangan.

Hal yang dapat diperhatikan sebagai pengembangan aplikasi lebih lanjut adalah aplikasi ini dapat dikembangkan mengarah ke aplikasi mobile sehingga mahasiswa dapat dengan mudah mengakses dan memperoleh informasi kegiatan yang akan dilaksanakan oleh kampus.

\section{DAFTAR RUJUKAN}

Jogianto (2008). Sistem Teknologi Informasi EDISI III. Yogyakarta: Andi.

Kadir, Abdul. (2006). Dasar Pemrograman Web Dinamis Menggunakan PHP.Yogyakarta: Andi.

Kristanto,A.(2008). Perancangan Sistem Informasi dan Aplikasinya Edisi Revisi. Yogyakarta: Gava Media.

Nugroho, Bunafit. (2005). Database Relasional dengan MySQL. Yogyakarta: Andi.

Peranginangin, Kasiman. (2006). Aplikasi WEB dengan PHP dan MySQL. Yogyakarta: Andi

Pohan, Husni Iskandar dan Bakri,Kusnassriyanto Saiful. 1997. Pengantar Perancangan Sistem.

Surabaya: Erlangga. 
Rima Aditya, Bayu \& Rahmat Iskandar, Ade. (2015). Aplikasi Informasi Kegiatan Mahasiswa di Fakultas Ilmu Terapan Universitas Telkom Berbasis Android dan SMS Broadcast. EProceeding of Applied Science. Vol 1 No 3. ISSN: 2442-5826. Page 1823.

Simarmata, Janner.(2010). Rekayasa Perangkat Lunak.Yogyakarta:Andi. 